\title{
HEIDEGGER E O ENIGMA DA COMÉDIA $^{1,2}$
}

\section{Róbson Ramos dos Reis (UFSM) ${ }^{3}$}

reis@smail.ufsm.br

Resumo: $\mathrm{O}$ objetivo deste artigo é a formulação de uma hipótese que estabeleça a conexão interna entre o risível e o pensamento do ser, oferecendo algumas direções para um tratamento sistemático do problema do cômico na obra de Heidegger. O artigo é concluído com um comentário sobre a relação entre o cômico, o trágico e o pensamento, tomando por base a interpretação heideggeriana de Heráclito.

Palavras-chave: Heidegger, cômico, riso, pensamento do ser.

\section{ESQUECIMENTO DO RISÍVEL?}

A história do tratamento do cômico mostra que há muito tempo o riso e o risível já foram reconhecidos como dignos objetos do pensamento. Porém, ainda hoje são poucos os trabalhos sobre o risível que escapam da conhecida declaração de Cícero (De oratore, II, p. 217):

Um dia em que pus as mãos em certas obras gregas que tinham por título $\mathrm{O}$ que faz rir, tive a esperança de que me ensinassem algo. Nelas achei um bom número daquelas piadas picantes tão comuns entre os gregos [...], mas quando elas quiseram formular a teoria do risível e

\footnotetext{
${ }^{1}$ Recebido: $14.10 .2010 /$ Aprovado: 29.10.2010/Publicado on-line: 08/12/2010.

${ }^{2}$ Agradeço os comentários dos participantes do XI Colóquio Heidegger: Heidegger e a arte (São Paulo, 2006), no qual foi apresentada uma versão reduzida da presente contribuição. Este trabalho recebeu o apoio do CNPq.

${ }^{3}$ Róbson Ramos dos Reis é professor-adjunto do departamento de filosofia da Universidade Federal de Santa Maria, Santa Maria, Rio Grande do Sul e pesquisador do CNPq.
} 
reduzi-lo a preceitos, mostraram-se singularmente insípidas, a tal ponto que, se fazem rir, é por causa de sua insipidez.

Não é por acaso que as obras de Heidegger estão mais próximas do maneirismo do que do cômico. Entre as suas questões não se acham perguntas como "O que significa rir?", "A pergunta pelo riso" ou "Sobre a essência da comédia". Há um esquecimento da comédia? Ora, a hermenêutica fenomenológica ensina a necessidade de apropriação dos conceitos fundamentais da história da filosofia. Sendo assim, a tarefa de pensar o impensado da tradição não poderia ser continuada em relação ao próprio pensamento do ser? Se o riso e o cômico estão impensados nos escritos de Heidegger, então as perguntas pela origem da obra de arte e pela essência poética da linguagem não estarão sob uma nova luz, caso sejam vistas a partir do horizonte do risível?

As observações que seguem têm por objetivo a preparação de um marco referencial e não visam uma resposta exegética desenvolvida. No entanto, para afastar a impressão de artificialidade do tópico, é suficiente lembrar que para certas teorias estéticas o risível somente pode ser definido por recurso ao seu contraponto: o sublime. Nesse sentido, iniciarei com a reconstrução de uma abordagem recentemente publicada da relação entre o risível e o sublime na obra de Heidegger. A seguir, comentarei quatro passagens em que Heidegger expressamente se refere ao ridículo e ao rir. $\mathrm{Na}$ terceira seção, buscarei a admissão da hipótese de uma conexão interna entre o risível e o pensamento do ser. $\mathrm{Na}$ quarta seção, apontarei algumas direções para um tratamento sistemático do problema do risível e do cômico na obra de Heidegger. Por fim, comentarei uma abordagem recente da relação entre o cômico, o trágico e o pensamento, elaborada a partir da interpretação heideggeriana de Heráclito. 


\section{SOBRE O SUBLIME E O SATÍRICO NA OBRA DE HEIDEGGER}

Partindo do fato de que nenhum outro pensador da mesma envergadura filosófica de Heidegger despertou tanto efeito satírico, Dieter Tomä (2003a, 2003b) sustentou que tal força evocativa da sátira é digna de ser pensada. Perguntar pelo que há de risível na filosofia de Heidegger não é mais uma contribuição para a diminuição e desvalorização exercitada por alguns críticos. Ao contrário, talvez o elemento satírico esteja ligado a certos aspectos internos da filosofia heideggeriana, não sendo um acaso ela ter motivado uma história de sátiras. Entender essa relação interna é contribuir para uma melhor compreensão de um pensamento que, a contragosto, inspira a sátira e a comédia.

Dieter Tomä (2003b) esboça inicialmente uma pequena história da sátira ao pensamento de Heidegger. A crônica inicia com pronunciamentos do irmão, Fritz Heidegger, e transita por registros epistolares, textos literários, peças teatrais e até mesmo uma canção do rapper alemão Thomas Pigor. Thomas Mann, Armin Eichholtz, Gabriel Marcel, Oskar Maria Graf, Günther Grass, Carl Schmitt, Thomas Bernhard, Elfriede Jelinek, Arnold Stadler são os escritores referidos. $\mathrm{O}$ motivo fundamental de tais sátiras encontra-se na linguagem única em que se expressa o pensamento heideggeriano, em particular na relação com a língua alemã e na pretensa ligação entre a pátria e o pensamento do ser.

Perseguir, na obra de Heidegger, aquilo que possui um potencial cômico exige, contudo, um procedimento indireto. Essa abordagem é necessária não apenas porque os principais escritos de Heidegger estão afastados de qualquer inclinação para o cômico, mas também porque neles há 
uma notória falta de proeminência do risível. A tese de Dieter Tomä parte de uma lei de simetria retirada da estética de Jean Paul, segundo a qual o cômico é o inimigo hereditário do sublime. O sublime rapidamente pode se tornar cômico, ridículo, risível. Assim, Heidegger desencadeia um efeito risível, porque pretende ter uma correspondência privilegiada com o sublime.

Após uma comparação com o tratamento do sentimento do sublime na estética de Kant (sobretudo do assim chamado dinâmico-sublime na natureza) e na pósmodernidade (Lyotard, em especial), Tomä destaca a presença de algo próximo ao sublime na obra de Heidegger. $\mathrm{O}$ acontecer de ser na história da humanidade e da metafísica possui aquele elemento irrepresentável e inconcebível que é identificado nas teorias clássicas do sublime. Há um acontecer não objetual, que, ao começar uma história de confusão entre ser e ente, encontra na linguagem da filosofia e na linguagem comum um poder de perda e ocultamento que inviabiliza a apreensão e a nomeação. "Ser" permite o acesso a tudo no mesmo movimento em que se retira e fecha o caminho até si. Para uma filosofia que pretende superar o subjetivismo, não é possível admitir que os homens tenham a autonomia para assumir livremente uma atitude em face desse poder sobrepujante. Diante do segredo, do enigma oculto que tudo domina e faz acessível, enfim, diante do mistério, não há nenhuma capacidade humana de resistência ou de conceitualização totalizadora.

Com a identificação da sublimidade no centro do pensamento do ser, é possível apontar para aquilo que promove a virada do sublime em cômico. A filosofia de Heidegger apresenta-se como apoiada e determinada por esse elemento estranho, assumindo para si a tarefa de preservar e prote- 
ger o enigma irrepresentável do outro do pensamento. Nesse sentido, é como se o filósofo visse a si mesmo sob a autoridade do impensado. A linguagem comum e a filosofia caem no poço da errância, mas a do próprio Heidegger não. O pensamento do mestre da Alemanha persegue o envio do irrepresentável como se possuísse a representação diplomática do ser. Ao embaixador do ser está entregue a tarefa de levar o irrepresentável ao conceito, pensando o que é poetizado pelos poetas. Assim, o segredo está descerrado, gerando um paradoxal efeito de monopolização do inalcançável, no qual quase não se pode distinguir se a linguagem de Heidegger está fundada no ser ou o contrário (TOMÄ, 2003a, p.106).

Essa autoatribuição de exclusividade no jogo do desocultamento faz com que o ser se transforme em uma variável da própria linguagem do pensador. Com isso, o irrepresentável está rompido, o segredo está revelado. Da nascente do Danúbio chega um pensamento apto para lidar de modo familiar com o estranho e terrível, um pensamento que fala a linguagem de quem conhece a intimidade do poder dominante. E no mesmo gesto em que se aproxima do sublime cai sob a lei de simetria estética: o sublime dá lugar ao risível. A linguagem do pensamento do ser está tão marcada por anamorfoses, inversões, variações verbais e circulações em torno de si mesma (e também em torno do solo originário da pátria), que Heidegger tropeça no próprio dizer $^{4}$. Alçando-se até o mais elevado, despenca para o mais

\footnotetext{
${ }^{4}$ Para analisar a estratégia interpretativa do método heideggeriano como um todo, Ernildo Stein introduziu a noção de anamorfose - a formação torcida de uma perspectiva sobre uma perspectiva. Segundo ele (1996, p. 34-35), as consequências teóricas da anarquia regrada são graves, pois implicam um avanço para além do maneirismo, gerando um efeito simulador de profundidade e uma sedutora transformação: aquilo que é apenas interpretação e narcisismo torna-se uma teoria com justificações arbitrárias.
} 
baixo. Segundo Dieter Tomä, o contraste entre a língua dos poetas e as interpretações de Heidegger exibe muito bem a inversão na gangorra do sublime e do ridículo, que alcança o ponto culminante quando o filósofo pretende ser também o poeta (TOMÄ, 2003a, p. 107). O pensar e a palavra do filósofo tornam-se involuntariamente o teatro em que o passo do sublime ao ridículo é dado com decisão.

Em síntese, as sátiras desencadeadas a partir da obra de Heidegger não são exteriores, e, abstraindo-se da má vontade inerente à ridicularização, elas revelam um traço importante no acontecer da filosofia heideggeriana. $O$ ponto de apoio dessa história cômico-efeitual localiza-se no modo em que o problema do ser aproxima-se do sublime. $O$ pensador essencial teria encontrado na poesia da pátria uma brecha para escapar do destino da história da metafísica, uma linguagem única que habitaria as margens do sublime, preparando uma nomeação do ser e correspondendo ao sagrado e ao enigma. A intimidade com o que é estranho, terrível, enigmático e oculto institui uma linguagem que é a embaixatriz do acontecimento do ser, rompendo com a esperada tensão entre o que é inalcançável e a sua nomeação. Carregando os traços inconfundíveis da língua pátria e da província, o tropeço na linguagem tomba de alturas sublimes, caindo no solo do risível (TOMÄ, 2003a, p. 108).

A tese de Dieter Tomä merece ser acolhida para aprofundamento e avaliação. Ela é relevante para os meus propósitos, porque abre uma via de tratamento do problema do cômico na obra de Heidegger. Não obstante, não creio que essa seja a única trilha promissora. Diferentemente de afirmar que o risível é impensável na obra de Heidegger (TOMÄ, 2003a, p. 99), pretendo que seja admissível conceber o cômico e o risível como o impensado dessa filosofia. 
Essa seria uma hipótese hermenêutica para examinar sob outra ótica os tópicos centrais da relação entre arte e ser. Por exemplo, em que medida não está, no núcleo poético da linguagem, aquele elemento que permite o riso, e que tipo de riso seria esse? Qual a relação entre o logos e o risível? A coisa na quadrindade pode ser risível? Ou ainda, não haveria outra acepção para o riso a partir do campo ontológico em que estão reunidos o acontecer histórico de um povo, o conflito na instauração dos sentidos de ser, a pertinência recíproca de ocultamento e desocultamento, a copertinência de ser e nada?

No extremo caberia perguntar se resultaria do projeto de superação da estética (HEIDEGGER, 1989a, p. 503) um modo de relacionamento tal com a obra de arte que formasse no elemento festivo e no jogo aquilo que é primariamente o risível. Assim sendo, não seria artificial perguntar pelo lugar da comédia na origem da obra de arte, ou seja, perguntar pela verdade da comédia e do risível. No momento não tenho os elementos para abordar esses problemas. Assim, como um movimento preparatório, examinarei quatro fragmentos de escritos de Heidegger em que são feitas observações sobre o elemento risível.

\section{PASSAGEM PELO RISÍVEL}

Há pelo menos quatro passagens em que Heidegger se refere expressamente ao ridículo, ao rir e ao risível. Nessas passagens há uma relação entre o risível, a ciência, a arte e a filosofia. A primeira ocorre ao final de Que é Metafísica? (1929). A segunda pertence à primeira versão do texto de $A$ origem da obra de arte (1989a). A terceira aparece em A pergunta pela coisa (1962), e a quarta aparece no curso de in- 
verno Sobre a essência da verdade (1931-1932). A respeito da alegoria da caverna e o Teeteto de Platão. Essas referências podem servir como indicações para responder às seguintes perguntas: o que Heidegger considera digno do riso e que concepção do cômico forma o horizonte não temático de identificação de algo como algo risível?

\subsection{A CIÊNCIA COMO PAIXÃO E SEU DESENRAIZAMENTO}

A conferência Que é Metafísica? parte da constatação de que a ciência tornou-se uma paixão desenraizada. A especialização e a profissionalização na investigação científica indicam um modo de existir desenraizado. Para encontrar um seguro enraizamento da existência científica é preciso admitir o vínculo íntimo entre ciência e metafísica, o que será obtido pelo reconhecimento da base limítrofe sobre a qual se ergue todo comportamento para com entes: a existência humana que compreende ser. Em última instância, a formulação adequada do problema do ser deve conduzir a uma tematização correta do fenômeno do nada. $\bigcirc$ nada não é a negação completa dos entes, mas indica a contingência de todas as formas pelas quais algo aparece como algo: aquilo que é condição do aparecer de algo não é uma propriedade fundada nos entes ou dedutível transcendentalmente. Tendo chegado a um conceito apropriado de nada, Heidegger enfoca a relação entre o conhecer científico dos objetos e a atitude que pretende elidir qualquer referência ao fenômeno do nada. Ao perder o enraizamento na existência humana finita, a seriedade do modo de existir científico revela-se como risível. Nas palavras de Heidegger (1929, p. 40-41):

O ser-aí científico recebe a sua simplicidade e acribia do fato de se relacionar com o ente e unicamente com ele de modo especialíssimo. A 
ciência quisera abandonar, com um gesto sobranceiro, o nada. Agora, porém, se torna patente na interrogação pelo nada que este ser-aí científico somente é possível se ele se retém previamente no nada. Ele só se compreende realmente naquilo que é, quando não abandona o nada. A aparente sobriedade e superioridade da ciência transforma-se em ridículo (Lächerlichkeit) se não leva a sério o nada. Somente porque o nada é manifesto a ciência pode transformar o próprio ente em objeto da investigação.

O argumento é bem conhecido. Com a nadificação acontece um movimento em que o ente no seu todo se põe em fuga, solapando as bases que instituem toda identidade e diferença. É nesse mesmo movimento que se apresenta para o ser-aí a diferença entre os entes e as condições do aparecer determinado de entes. O desvelar-se do nada, por sua vez, conduz ao estranhamento e admiração em face dos entes. Surge a pergunta pelo porque, e, em última instância, a pesquisa científica dos objetos. $\mathrm{O}$ fundamento da ciência está no nada. A pergunta pelos razões origina-se do que não tem nenhum por que. A normatividade do desvelamento de ser que possibilita a atitude científica é livre, porque a subordinação à medida real da verdade não é necessária. A sobriedade e superioridade da ciência - a limitação crítica e o rigor objetivo - tornam-se ridículas quando se ignora o fundamento do comportamento científico naquilo que não é ente, fundamento que a própria ciência não é capaz de tematizar ${ }^{5}$. Em última instância, a falta de reconhecimento da copertinência entre ser e nada torna risível a seriedade da sóbria ciência.

No presente uso da palavra "ridículo" são visíveis os

\footnotetext{
${ }^{5} \mathrm{Na}$ Preleção sobre o Sofista, Heidegger (1992, p. 373) também qualifica como ridícula a maneira como se entende a noção de Bildung, tomada como uma posse de conhecimentos e não como a capacidade de investigar, isto é, como uma tarefa que supõe o enfrentamento com as próprias resistências.
} 
traços de uma descendência platônica. No Filebo encontrase aquela que é considerada a mais antiga formulação teórica sobre o riso e o risível (ALBERTI, 40, Filebo 48a-50d). A tônica da abordagem é a condenação moral do que é risível e daquele que ri: em ambos acontece um mal. O objeto do riso é portador de um vício, pois não segue a recomendação do oráculo de Delfos: “conhece-te a ti mesmo". Risíveis são aqueles que se desconhecem e se tornam vítimas da ilusão: consideram-se mais ricos e mais belos do que de fato são. Porém, quando trajam o véu da ilusão, as qualidades da alma representam os principais fatores que tornam uma pessoa ridícula ou risível: julgar-se superior em virtude ou em sabedoria, quando em verdade nada disso se é. No entanto, apenas essa condição não é suficiente para tornar alguém risível. É preciso que esses homens sejam fracos. Homens fortes e ignorantes tornam-se temíveis ou odiáveis, mas não risíveis. Os que não têm força caem sob o manto do ridículo: o fraco que se imagina mais sábio, mais belo, mais rico ou mais virtuoso do que é.

A ciência não é uma pessoa, é certo, mas a existência científica é um modo possível de existir do ser-aí. Exclusivamente orientada para o descobrimento teórico e a verdade, ela cai no vício da ignorância ao pretender saber mais do que realmente sabe, desconhecendo seus próprios fundamentos e condições de possibilidade. A sobriedade, por outro lado, também é uma ilusão, pois a suposta limitação repousa em uma transgressão categorial, que se estende acriticamente sobre aquilo que é seu fundamento e para o qual não está metodologicamente aparelhada. A superioridade também é uma ilusão, pois, ao pretender estar fora de toda metafísica, a ciência ignora que está mergulhada não apenas na metafísica, mas naquilo que põe toda a metafísica 
em questão. Está satisfeita a primeira condição para a ciência tornar-se ridícula: o vício da ignorância.

Quanto ao traço de fraqueza, as premissas da ontologia fundamental podem identificar uma impotência definitória no modo de existir científico, pois a paixão científica não consegue se recuperar autonomamente do desenraizamento. Apenas acontecimentos não cognitivos operantes na existência teórica, como a angústia, poderiam desencadear uma lógica produtiva e uma fundação filosófica da ciência. Somente com uma abordagem ontológico-existencial são descobertos os retos fundamentos da ciência, a saber: a compreensão de ser, a temporalidade e historicidade de ser e, portanto, a mútua determinação entre ser e nada. Comparada com a filosofia, que se saberia impotente, a séria ciência sofreria de uma fraqueza ignara, sendo ridícula. Com o pensamento sobre a técnica, no contexto da história do ser, talvez seja a força da ciência que venha para o primeiro plano, sendo mais propriamente temível (ou odiável) do que risível. Quanto aos elementos de condenação moral, o vício da ignorância no objeto do riso e a confusão entre inveja e prazer naquele que ri, também não está claro que estejam presentes no uso da palavra "ridículo". Seja como for, não é artificial afirmar que a citada avaliação da ciência é tributária de aspectos da doutrina platônica do riso.

\subsection{A GARGALHADA DO MECÂNICO}

A segunda passagem que comentarei integra a primeira versão das conferências que resultaram no ensaio sobre A origem da obra de arte. Ela é relevante por ser um dos poucos 
textos em que Heidegger se permite uma retórica cômica ${ }^{6}$. Referindo-se ao conceito de expressão como definitório da essência da obra de arte, ele (1989a, p. 17-18) afirma:

Seja concedido de antemão que a determinação da arte como expressão possui a sua correção. A opinião que a arte é expressão é tão indiscutivel quanto o enunciado: a motocicleta é algo que faz barulho. Todo técnico daria uma gargalhada diante de tal determinação da essência dessa máquina. Porém, ninguém ri quando desde há muito se fala por aí que a arte é "expressão". Certamente, a acrópole é expressão dos gregos, e a catedral de Naumburg é expressão dos alemães, e o mé (Mäh) é expressão da ovelha. Sim, a obra de arte provavelmente é até mesmo uma expressão peculiar, quer dizer, um mé muito próprio. Mas a obra não é obra porque seja expressão, mas sim é expressão porque é uma obra. A designação da obra como expressão não apenas não contribui em nada para a determinação do ser-obra, senão que já impede toda genuína pergunta por este ser (Seyn).

Convém lembrar que Heidegger voltou a considerar a palavra "mé" e o balido das ovelhas no seminário sobre Herder, ministrado no verão de $1939^{7}$. Nesse contexto, não há um uso retórico da onomatopéia, mas uma reconstrução e interpretação do exemplo do balido da ovelha oferecido por Herder. No Ensaio sobre a origem da linguagem, Herder esboça uma análise da gênese da linguagem a partir de elementos primitivos que seriam de natureza sonora e dinâmica. Heidegger analisa os dois momentos em que aparece o exemplo do balido da ovelha. No primeiro caso, quando

\footnotetext{
${ }^{6} \mathrm{O}$ ensaio sobre A origem da obra de arte tem por base uma conferência que recebeu três versões escritas entre 1935 e 1936. A terceira versão foi publicada em 1949. A segunda versão foi proferida em 13.11.1935 e publicada em francês à revelia dos editores da obra de Heidegger. A primeira versão nunca foi apresentada e somente veio a público em 1989, no Heidegger Studien 5. A passagem a seguir não foi preservada no texto publicado em 1949 e desconheço se foi mantida na segunda versão da conferência.

${ }^{7}$ Agradeço a Caue Cardoso Polla pela relevante observação sobre o tratamento do exemplo de Herder a respeito do balido das ovelhas. O tópico foi abordado por Heidegger no seminário do verão de 1939 sobre o Ensaio sobre a origem da linguagem. Do seminário de Heidegger foram preservadas anotações e esboços, além de 11 protocolos redigidos pelos estudantes presentes (HEIDEGGER, 1999).
} 
surge a necessidade de representar um ente como ente e como idêntico a si mesmo, é preciso que se faça uma diferenciação, que requer um termo de comparação. Este, segundo Herder, seria de natureza acústica. Um som, o balido da ovelha, é o elemento a partir do qual é possível chegar à sentença "Tu és aquilo que bale". Nesse caso, a ovelha aparece apenas como um ente que pode ser encontrado a partir dos sentidos (HEIDEGGER, 1999, p. 192).

A segunda referência é menos casual, pois a ovelha é encontrada como um ente que emite sons. $\mathrm{Na}$ concepção de Herder, o som, a audição e a imagem sonora devem estar em primeiro plano para a consideração da origem da linguagem. Assim, a criança vê uma ovelha e escuta o balir. $\mathrm{Na}$ reconstrução de Heidegger, a criança aponta com o dedo e diz "mé". Ao fazer isso ela pretende dizer, por exemplo, "Tu és aquilo que faz mé", "Tu és o mé" Desse modo, um ente singular é notado e nomeado como sendo "o mé". O que se processou nesse movimento foi a passagem de uma palavra que nomeia uma marca sonora para uma palavra em sentido pleno. De acordo com Heidegger (1999, p. 194), o "mé" dito pela criança mostra-se como uma marca característica sonora e como uma palavra soante.

Das anotações e dos protocolos das aulas é possível observar que Heidegger considera o exemplo de Herder para afirmar que a percepção sonora jamais é um mero captar de ruídos ou sons. Consoante à hermenêutica da percepção sonora já formulada em Ser e tempo, ele pode afirmar que sempre ouvimos algo determinado e que por isso o som não está subordinado apenas ao ouvido. Em relação a frases como "Lá está o mé", Heidegger afirma que o propriamente dito não é aquilo que foi escutado, mas o silêncio, o ser, o silencioso ("die Stille, das Seyn, das Lautlose", 
HEIDEGGER, 1999, p 137). O desvelamento de ser é condição da percepção e da formulação de sentenças predicativas, e até mesmo daquelas que identificam entes com expressões ocasionais. Deve ser ressaltado que a reconstrução de Heidegger se mantém nos limites do ensaio de Herder e não apresenta o sentido crítico que a onomatopéia recebe na passagem acima citada.

Retornando à citação, não é artificial afirmar que o uso da palavra "mé" cumpre uma importante função retórica. Duas sentenças são comparadas em relação ao efeito cômico que produzem, quando são usadas com uma pretensão de enunciar uma informação relevante. $O$ fator cômico não está na trivialidade informacional nelas contidas, mas na associação com a pretensão de não ser uma informação trivial. Em um caso, o elemento risível é de efeito imediato, no outro não. A trivialidade do enunciado resulta do conhecimento das informações das quais ele pode ser inferido sem mais dificuldades. Assim, para um mecânico, um técnico em motores, a sentença "A motocicleta faz barulho" produz uma gargalhada quando proferida por alguém que, com isso, pretendesse enunciar algo novo e essencial sobre essa máquina.

Nesse caso, a doutrina mais apropriada para elucidar o fato cômico apontado por Heidegger não é tanto a de Platão, mas sim a de Aristóteles. Apesar das dificuldades surgidas da falta do Livro II da Poética, alguns componentes da teoria aristotélica da comédia nos são conhecidos. Em primeiro lugar, há a ausência da avaliação moral do riso e do objeto do riso, retirando o aspecto de condenação na identificação de algo ridículo ou de alguém que ri. Mais importante é a definição do cômico como uma parte do torpe, isto é, um defeito ou torpeza que não causa dor ou destrui- 
ção (ARISTÓTELES, Poética, 5). O defeito cômico é inofensivo, não causa temor nem ódio (portanto, não causa terror nem piedade).

Um importante passo na teoria do cômico, conhecido a partir do texto anônimo chamado de Tractatus Coislinianus (COOPER e ALADRO, 2002), é a diferença entre cômico de lexis e cômico de pragmata. Risíveis são as expressões da língua, o que é dito, ou a ação, as coisas e eventos. No Tractatus são nomeados sete tipos do primeiro gênero - homonímia, paronímia, erros de gramática, forma diminutiva de expressão infantil, etc. - e nove do segundo, por exemplo, modificação da história, assimilação do melhor ao pior, o inesperado ou surpresa, a escolha do pior quando se poderia escolher o melhor, etc. Essa distinção é central para os grandes tratamentos sistemáticos do riso na retórica romana, em Cícero e em Quintiliano (ver ALBERTI, 1999, cap. 2). É relevante para a interpretação da passagem a divisão entre os risíveis de palavras e os risíveis de coisas, em que "coisa" não é um objeto referencial, mas aquilo que no discurso não se constitui em figura de estilo. $\mathrm{O}$ risível está na ação de enunciar uma frase, que em si mesma não é risível, com a pretensão de veicular uma informação nova e essencial, mas que de fato não é nada disso.

A outra sentença - "A arte é expressão" - não produz um efeito cômico, e Heidegger ressalta a diferença entre dois enunciados que deveriam proporcionar o mesmo efeito. Os que preservam o enigma da arte cairiam na gargalhada ao ouvir tal sentença, caso ela estivesse acompanhada da pretensão de enunciar uma informação nova e essencial em relação à arte. No entanto, isso não acontece. O efeito cômico não é o caso, e a razão é que não se reconhece a trivialidade que a sentença enuncia. Para gerar o 
reconhecimento da trivialidade, Heidegger apela para um recurso retórico de satirização, que proporciona um efeito cômico. Usando dois recursos da comédia, o uso de uma onomatopéia (a palavra "mé", e não o verbo "balir") e um risível de coisas pela assimilação do supostamente melhor ao supostamente pior (assimilar a edificação de uma catedral à emissão de um som por um animal), ele apresenta como risível o enunciado "A arte é expressão". Esse enunciado é trivial, pois é seguido da premissa geral que entes vivos produzem efeitos sensíveis pela ação dos seus organismos, seja o braço ou as cordas vocais. A arte é um "me" muito especial, ou seja, a Acrópole e a catedral de Naumburg são expressões peculiares, mas que em certa medida são expressivas do mesmo modo, como o balido ou o latido.

No entanto, esse mesmo enunciado será trivializado de outra maneira, quando se reconhecer que o conceito de expressão é subordinado ao conceito de obra. A noção de expressão não pode designar nada de essencial sobre a arte, pois a obra de arte somente é expressão por já ser obra de arte. Ora, iniciar uma consideração sobre o que significa ser obra de arte é precisamente a meta das indicações de Heidegger sobre a origem da obra de arte. Por sua vez, tais indicações são integrantes de uma preparação para o ultrapassamento da estética, entendido como parte do ultrapassamento da metafísica ${ }^{8}$. A conclusão é elementar: no ultrapassamento da metafísica será compreendida a origem

\footnotetext{
${ }^{8} \mathrm{Na}$ edição Reclam de A origem da obra de arte, Heidegger (1977, p. 73) afirmou que "O que é a arte é uma daquelas questões para as quais não é oferecida nenhuma resposta no ensaio. Aquilo que tem a aparência de ser uma tal coisa são diretivas para o perguntar". No início do posfácio, ele (idem, p. 67) escreve que "As considerações precedentes lidam com o enigma da arte, o enigma que é a própria arte. A pretensão está distante de solucionar o enigma. A tarefa é apenas colocar o enigma".
} 
da obra de arte, e a sentença "A arte é expressão" será trivial. Ao ser proferida com pretensão de novidade, fará rir. Para o pensador pós-metafísico, que experimenta o por em obra da verdade, isto é, o acontecer de um projeto de verdade na contenda entre terra e mundo, será trivial afirmar que a arte é expressão. Dele pode-se esperar o riso diante dessa definição pretensamente essencial.

O conceito de expressão é central para a estética que concebe a obra como o veículo de um sentido ou de um valor não sensível ${ }^{9}$. Esse elemento superestrutural teria sido concebido pelo artista e inserido como forma na matéria de que é feita a obra. O sentido pode, então, ser recebido por quem experimenta a obra de arte na relação estética. Contudo, apesar de ser tão central para a estética, o conceito de expressão bloqueia o acesso adequado ao ser (Seyn) da obra de arte. Consequentemente, a superação da estética contempla uma recusa qualificada do conceito de expressão. No entanto, algo da noção deve permanecer após a adequada conceitualização da obra de arte, mesmo que implique uma trivialidade. Essa trivialização, no entanto, é distinta daquela revelada pela analogia da edificação de uma catedral com o balido das ovelhas. Nesse ponto, seria plausível perguntar se o conceito de mímese, central para a crítica heideggeriana da estética, não estaria preservado em outro plano, após a elucidação da obra de arte no contexto do acontecimento apropriativo (SALLIS, 1992; IJSSELING, 1993).

A passagem citada sugere que um enunciado categórico sobre a arte pode ser feito risível, por exemplo, usando um

\footnotetext{
${ }^{9}$ Sobre a noção de estética e a correspondente concepção de arte que são o objeto da desconstrução heideggeriana, ver Young (2001, p. 5-16).
} 
recurso satírico. Caso seja obtido o efeito cômico, então teremos compreendido a trivialidade do enunciado. Por um lado, a obviedade da sentença deriva de premissas evidentes, ou então, de outro, porque já se está a caminho de compreender o ser da obra de arte em relação com o conceito de expressão. Ao vislumbrar o cômico do enunciado sobre a arte como expressão, pela piada que descreve a expressividade artística com uma onomatopéia, poderemos retirar o empecilho para chegar à trivialização, compreendendo o ser da obra. Se rimos é porque, assim como o mecânico que sabe que uma motocicleta faz barulho, adquirimos um novo modo de estar em face da obra de arte. A metafísica e a estética terão sido reconhecidas como aguardando ultrapassamento ${ }^{10}$.

Não pretendo insistir artificialmente no aceno que o riso pode proporcionar para o ultrapassamento da metafísica. A onomatopéia também conduz para a simbologia religiosa, o sacrifício. Lembremos que, segundo uma passagem central de A origem da obra de arte, o sacrifício essencial é uma das maneiras pelas quais acontece a fundação da verdade, juntamente com a fundação do estado e com a obra de arte (HEIDEGGER, 1977, p. 49) ${ }^{11}$. A relação entre arte e sacrifício não parece ser tão trivial quanto a relação entre arte e

\footnotetext{
${ }^{10}$ Sobre a reconstrução da superação da estética a partir das novas fontes textuais disponíveis, ver Trawny (1994). Na primeira versão da conferência sobre A origem da obra de arte, Heidegger (1989a, p. 5) afirma explicitamente que somente lhe interessa uma coisa: preparar uma posição fundamental transformada do nosso ser-aí em relação à arte. Nos Beiträge zur Philosophie, afirma: "A pergunta pela origem da obra de arte não pretende uma constatação atemporalmente válida da essência da obra de arte, que também pudesse servir como fio condutor para uma explicação historicamente retrospectiva da história da arte. A questão está na mais interna conexão com a tarefa de superação da estética e isto quer dizer também com uma concepção determinada do ente como o objetualmente representável. A superação da estética, por sua vez, resulta como necessária a partir da discussão histórica com a metafísica como tal” (HEIDEGGER, 1989b, p. 503).

${ }^{11}$ Sobre a obra de arte como sacrifício, ver Fóti (1999, p. 169).
} 
expressão. Em suma, aquele que compreende a piada de Heidegger, caso seja mesmo um recurso cômico, não apenas desloca o conceito metafísico de expressão, mas também entende o justo sentido em que a obra é expressão. Como sacrifício, ela apresenta a fundação do ser no ente, a escultura do mundo sobre a terra. A arte é expressão porque pertence ao que acontece na forma do sacrifício, ao que se desvela no mesmo gesto em que se oculta.

\subsection{RIR DA FILOSOFIA}

A terceira passagem é muito conhecida e aparece em A pergunta pela coisa. À pergunta pela coisa liga-se uma célebre história da antiguidade, distinguida com a não menos conhecida passagem do Teeteto, em que Platão relata o riso da criada Trácia pela queda de Tales. Platão acrescentou que o mesmo escárnio aplica-se a todos que se ocupam da filosofia (HEIDEGGER, 1962, p. 2). A pergunta pela coisidade da coisa pertence àquelas questões que não servem para nada e sobre a qual nada mais precisa ser dito. Nesse contexto, afirma:

Portanto, devemos determinar a questão 'que é uma coisa?' como uma daquelas de que as criadas se riem. E uma verdadeira criada deve ter sempre alguma coisa de que possa rir.

De súbito, com a caracterização da questão acerca do que é uma coisa, aproximamo-nos do que seja o característico da filosofia, que levanta tal questão. Filosofia é aquele modo de pensar que não serve essencialmente para nada, e acerca do qual as criadas necessariamente se riem.

Essa determinação conceitual da filosofia não é uma mera brincadeira, mas deve ser meditada. Fazemos bem em ocasionalmente nos lembrar que em nossos caminhos talvez nos aconteça cair num poço em que, durante muito tempo, não chegamos ao fundo. (HEIDEGGER, 1962, p. 2-3) 
A imagem da doença surge com frequência nas metáforas sobre a relação entre filosofar e errar. $\mathrm{O}$ funcionamento desregrado de capacidades gera pseudoproblemas que admitem uma terapêutica nem sempre definitiva. Por seu turno, a imagem do cômico é menos comprometida do que a da enfermidade, pois o fato de que alguém se torne risível (ou que não ria de uma piada) não o faz doente, menos humano, irracional ou imoral (COHEN, 1999, p. 29-32). Assim, sendo invertido para o entendimento comum, há que se rir do mundo dos filósofos. Entretanto, não é evidente que o poço seja a imagem de erros que podem ser evitados. Ao contrário, também para Heidegger há ilusões necessárias no caminho da filosofia. A relação entre fenômeno e encobrimento, por exemplo, é de tal ordem que a investigação fenomenológica está exposta ao constante retorno para o encobrimento. Por isso, a dificuldade da pesquisa fenomenológica reside em ter de voltar-se criticamente contra si mesma. Voltar-se contra si mesmo não é uma das características centrais do verdadeiro humor? Rir de si mesmo em vez de rir dos outros! A curiosa afirmação de Ser e tempo - "Wieviel Schein jedoch, so viel 'Sein'” (HEIDEGGER, 1927, p. 36) - pode ser lida como um princípio de uma fenomenologia do humor, mas também como a exigência de certo humor cômico, e não apenas melancólico, para levar adiante as coisas da filosofia.

É importante ressaltar que certa visão a respeito do erro na filosofia foi qualificada por Heidegger como "bem cômica”. No início do curso de verão de 1943 - Heráclito. A origem do pensamento ocidental - encontram-se as seguintes frases:

Traçaríamos uma imagem bem cômica (recht komisch) dos pensadores, se achássemos que eles pensam sem errar. Os pensadores essenciais 
são precisamente aqueles que pensam o verdadeiro, apesar dos vários erros que lhes 'ocorram'. Por isso, também a discussão entre pensadores possui um caráter e sentido bem diversos da crítica e polêmica, tão necessárias e habituais no campo das ciências. (HEIDEGGER, 1979, p. 41-42)

A passagem é relevante, pois declara explicitamente o sentido em que se pode falar de acerto e erro no pensamento essencial. Não há pensamento livre de erro quando se pensa o mesmo. Assim, a expressão "recht komisch" designa o despropósito de esperar um pensamento impecável ${ }^{12}$. O contexto temático é importante, pois também afasta a imagem usual da discussão entre pensadores como sendo apenas um exame crítico de erros e qualificando a imagem do progresso argumentativo ao longo da história da filosofia. Seria cômica a imagem de um pensamento que não errasse.

Voltando para a citação de A pergunta pela coisa: quem é a criada? Qual é a perspectiva da criada? E por que uma verdadeira criada? $\mathrm{O}$ texto sugere uma resposta ao equiparar a ótica da criada com a perspectiva comum. É o ponto de vista para o qual as perguntas filosóficas são as que não servem para nada (HEIDEGGER, 1962, p. 8). É a perspectiva para a qual este tipo de pergunta - o que é uma coisa? - é vazia e fantástica (idem, p. 36). Ao caracterizar as perguntas filosóficas como aquelas que supõem um procedimento de alto risco, Heidegger estabelece um vínculo interno entre a filosofia e aquilo que promove o riso. Trata-se do riso cômico

\footnotetext{
${ }^{12}$ A tradução brasileira do curso sobre Heráclito mantém o sentido figurado da palavra "komisch", que também pode significar "estranho". Não entrarei no mérito da escolha, porém, se é admissível compreender a palavra no sentido de "cômico", então acontece novamente a conversão em risível do que supostamente é sério: o pensamento que pretende não errar é bem cômico. Freydberg (2007, p. 255) declara com razão que essa passagem é aparentemente inócua, pois, de fato, não é evidente que nela esteja declarada a natureza cômica apenas da pretensão de um pensar sem erros.
} 
ou do riso trágico? ${ }^{13}$ Aqui não se estaria no limiar de outra categorização, algo assim como o riso originário, do qual os dois anteriores seriam derivações?

Aparentemente, a perspectiva da criada é a ótica comum, e não filosófica. No entanto, Heidegger (1962, p. 36) pergunta se tal perspectiva não poderia conter um dinamismo próprio: não somos nós mesmos a criada, quando dizemos que é fantástico e vazio indagar sobre o "isto" e a coisa? Portanto, é possível uma inversão tal que a perspectiva usual termina por valer como norma para os assuntos filosóficos. Caberia perguntar se esse movimento de inversão não pode ser levado totalmente a cabo, isto é, se afinal de contas não é exatamente a perspectiva da criada aquela que, por rir do pensamento exposto ao perigo e ao sem fundo, pode reconhecer esse pensamento como tal. Assim como para Meister Eckhart (1994, p. 170-179) há uma excelência de Marta sobre Maria, a excelência daquela que cuida da casa em relação àquela que se põe em ligação contemplativa com o Deus vivo. Assim, não estaria ironicamente sugerido no comentário de Heidegger (1962, p. 4) que também na perspectiva da criada, que ri do pensamento essencial, está a verdadeira ligação com o que é digno de ser pensado? Afinal de contas, aprende-se algo com o riso da criada.

No presente contexto, o poço é sinônimo daquilo que põe o filósofo em perigo e também do perigo de ser objeto do riso. Esse perigo pode estar, por exemplo, na historicidade da filosofia, na relação com o começo histórico e com a noção de avanço ou progresso filosófico. Haveria algo de risível no modo como pode acontecer a história da filosofia? Heidegger acredita que sim! No contexto de uma interpre-

\footnotetext{
${ }^{13}$ Sobre a distinção entre o riso cômico e o riso trágico, consultar Alberti (1999, p. 20-24).
} 


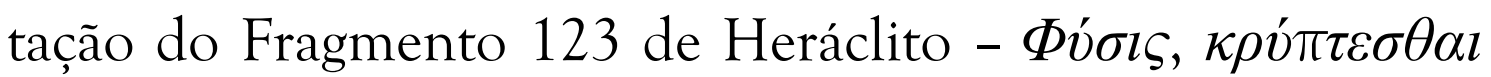
e $\varphi \imath \lambda \varepsilon \tilde{\imath}$ - que expressaria a experiência fundamental da qual surgiu um olhar sobre a essência da verdade como desocultamento, Heidegger comenta a relação entre o antigo e o primitivo, o antigo e o não claro. $\mathrm{O}$ começo seria primitivo? O começo seria o não claro? Ou o começo seria o grandioso? A passagem a seguir liga expressamente o ridículo com a falta de uma compreensão da relação entre a filosofia e o seu próprio começo ${ }^{14}$ :

Em todo inessencial e insignificante o começo é o que pode e será superado; portanto, no inessencial há progresso. Porém, no essencial, ao qual pertence a filosofia, o começo nunca pode ser superado; não apenas não ser superado, mas até mesmo não ser mais alcançado. No campo do essencial o começo é o inalcançável, o grandioso, e porque nós não concebermos mais nada disso, por isso em nós tudo é tão completamente arruinado, ridículo (lächerlich), tão desprovido de lei e completa ignorância. Filosofar sem esse começo vale hoje como algo superior. A filosofia possui sua própria lei; são outras as suas avaliações. (HEIDEGGER, 1988, p. 15)

É evidente, no comentário, a relação entre o grandioso e o ridículo. Quando não se reconhece que o começo é o insuperável e o inalcançável nas "coisas" essenciais, então o filosofar se arruína, tornando-se ridículo e risível. A história da filosofia pode encetar caminhos que levam ao riso, quando pretende superar o grandioso e inalcançável. Certa maneira de conceber a historicidade da filosofia torna-se risível ao pretender que o começo - por ser tateante e pouco claro tenha de ser superado. Por ora, é suficiente ressaltar que, sendo um comentário no contexto da interpretação das noções de $\Phi v ́ \sigma ı \varsigma$ e $\alpha \lambda \varepsilon \theta \varepsilon \imath \alpha$, o trecho citado por Heidegger su-

\footnotetext{
${ }^{14}$ A passagem está no curso de inverno de 1931-1932 (HEIDEGGER, 1988). Como é sabido, A pergunta pela coisa foi publicado em 1962, mas refere-se ao curso de inverno de 1935-1936; o curso sobre Heráclito é do verão de 1943.
} 
gere que certa atitude em relação à história dos conceitos de natureza e verdade poderia ser ridícula. A metafísica, que pensa a natureza como um domínio de objetos regulados por leis e a verdade como propriedade dos juízos, seria risível por tomar essas concepções como um progresso em relação aos sentidos originários do começo grego.

As citações analisadas oferecem apenas algumas pistas para se responder à pergunta sobre o que é o risível, segundo a ontologia fundamental e o pensamento do ser. $\mathrm{O}$ risível situa-se no desenraizamento da existência, na trivialidade do caráter expressivo da arte e na essência da própria filosofia. Nos três contextos há uma ligação entre o risível e a falta do pensamento sobre o ser: no esquecimento do ser, a existência científica torna-se risível, um enunciado trivial sobre a essência da arte não produz o efeito cômico, as perguntas ontológicas orientadas para ser inspiram o riso da atitude comum, e a pretensão de superar o começo inalcançável do filosofar torna-se ridícula. Contudo, essas avaliações pressupõem uma distância crítica em relação à metafísica e ao esquecimento de ser. A sobriedade da existência científica objetiva, a essencialidade da afirmação sobre a arte ser expressão, a normalidade da atitude comum diante das perguntas filosóficas e o esclarecimento associado ao progresso na história da filosofia aparecem como sérios apenas para uma posição externa ao pensamento do ser. Quando acontece de o pensamento ser movido para o plano de ser, então temos a inversão do sério em risível. Está presente, portanto, o modelo platônico do risível. Ridículo é o fraco que ignora sua própria impotência e se apresenta como potente e aprumado. Na próxima seção apresentarei algumas direções para o desenvolvimento da interpretação, que reconhece um vínculo positivo entre o riso 
e o pensamento sobre o ser, lembrando, mais uma vez, que meu propósito é apenas prender a atenção do leitor da obra de Heidegger, ou seja, chamar a atenção para o enigma do riso e do humor.

\section{HEIDEGGER E DEMÓCRITO}

Seria concebível uma relação entre o riso e o pensamento de ser que não fosse apenas a da função crítico-terapêutica do "humor verdadeiro" (CRITCHELEY, 2002, p. 15)? Na interpretação da anedota sobre Tales há uma sugestão de um poder salvífico do riso e do humor: se na filosofia é possível cair "por idades imensas", essa é uma queda que moverá ainda mais o riso, e um tipo especial de riso. Não é o poço o que dá à criada a ocasião de rir? E não é o riso aquilo que lembra ao filósofo que podem haver "caminhos que não levam a lugar algum"? Na retórica romana, o recurso ao riso permite prender ou melhorar a atenção do público ou do juiz. De modo análogo, não seria o riso aquilo que pode prender a atenção da perspectiva usual, ao mesmo tempo em que prende a atenção do filósofo ao acerto do seu caminho? Aqui não estaria antecipada aquela compreensão desenhada por Joachim Ritter (1940, p. 76), segundo a qual o filósofo precisa colocar o boné de bufão para chegar àquele recanto de onde pode alcançar o impensado?

Como atenção e pensamento estão vinculados, então aparentemente não há nada de artificial em relacionar o riso e o pensamento do ser. Quando a atenção é capturada, forma-se gratuitamente uma ligação, uma ligação que está 
presente, por exemplo, na intimidade do contar piadas ${ }^{15}$. Tal intimidade no humor revela uma ligação gratuita fundada na atenção. Seria possível que a atenção para com o ser possuísse algo da intimidade que acontece no humor? O riso diante das "quedas" filosóficas e o riso diante do pensamento essencial mostram que aconteceu uma ligação, uma intimidade entre a perspectiva comum e a filosófica: o pensamento do ser cativou a atenção e o riso reconhece a natureza das perguntas essenciais.

Com o propósito de avançar construtivamente no tema do risível no contexto da questão do ser, parece-me apropriado iniciar uma digressão lembrando as palavras de Montaigne (1984 I, L):

Demócrito e Heráclito eram dois filósofos. O primeiro, achando que a condição humana é vã e ridícula, apresentava-se sempre em público a rir e a motejar. Heráclito, tomado de piedade por essa mesma humanidade, andava permanentemente triste e de lágrimas nos olhos: 'Logo que punham o pé fora de casa, um ria e o outro chorava'. (Montaigne, 1984 I, L)

Um dos documentos que difundiu a imagem de Demócrito como "o filósofo que ri" é a famosa carta de PseudoHipócrates, aparentemente redigida na metade do século I a.C. (ALBERTI, 1999, p. 74). A carta relata uma história que relaciona loucura, riso e sabedoria. Os cidadãos de Abdera chamaram um terapeuta. O filósofo da cidade está acometido de loucura, porque ri de qualquer coisa! $\mathrm{O}$ filósofo ri copiosamente das histórias tristes que seus concidadãos lhe contam. Hipócrates encontra Demócrito sen-

\footnotetext{
${ }^{15}$ Ted Cohen $(1999$, p. 40) mostrou com pertinência que a apresentação de uma piada pode promover uma comunhão entre falante e ouvinte baseada no compartilhamento possível de certos conhecimentos e sentimentos. Quando a piada funciona, e o riso aparece, formou-se uma comunidade de diversão.
} 
tado ao pé de uma árvore, cercado de cadáveres de animais, escrevendo, pensando e examinando as vísceras de animais. Demócrito conta ao médico que está escrevendo um livro sobre a loucura. Ele investiga a origem da melancolia e a maneira de extirpá-la dos homens. O médico justifica-se por não se dedicar a tal nobre investigação, pois andaria ocupado demais, cuidando das doenças e das mortes, cuidando de crianças e de problemas domésticos. De pronto o filósofo ri abertamente. Diante dessa reação passional, Hipócrates pede uma explicação: não é absurdo rir da morte e das doenças, rir de coisas boas, sagradas e dignas? O que é belo e trágico pode ser objeto do riso? A resposta oferecida por Demócrito seria aproximadamente a seguinte:

Eu rio do homem cheio de loucura e vazio de toda ação direita, que [...] se comporta puerilmente, [...] que vai até o fim do mundo [...] procurando ouro e prata, $[. .$.$] trabalhando sempre para adquirir mais$ bens [...]. Eu rio também do homem que cava as entranhas e veias da terra, para as minas, [...] enquanto se podia contentar com aquilo que a terra, a mãe de todos, produz suficientemente para o sustento dos homens. Há os que querem ser grandes senhores e comandar muitos; há os que não conseguem se comandar a si mesmos. Eles se casam com mulheres que logo repudiam. Eles amam, depois odeiam. Eles são muito desejosos de ter filhos, e quando eles estão grandes, os mandam para longe. [...] Vivendo em excessos, eles não têm nenhuma preocupação com a indigência de seus amigos e de sua pátria. Eles perseguem coisas indignas [...]. Além disso, têm apetite por coisas penosas, porque aquele que mora em terra firme quereria estar no mar, e aquele que nele está quereria estar em terra firme. [...] Se os homens fizessem as coisas prudentemente, [...] me poupariam o riso. Mas, ao contrário, eles, como se as coisas fossem firmes e estáveis nesse mundo, vangloriam-se loucamente, sem poder reter sua impetuosidade, por faltar-lhes a boa razão, o discernimento, o julgamento. Porque esse único aviso lhes bastaria: de que todas as coisas têm seu turno, o qual advém por mudanças súbitas [...]. Eles, como se a coisa fosse firme e perdurável e esquecendo os acidentes que ocorrem ordinariamente, [...] se envolvem com várias calamidades. Se cada um pensasse fazer todas as coisas de acordo com seu poder, cer- 
tamente se sustentaria em uma vida certa e tranqüila, conhecer-se-ia a si mesmo, $[\ldots]$ contentando-se com as riquezas da natureza. [...] Eis o que me dá matéria de riso. Ó homens insensatos, vocês são bem punidos de sua loucura, avarice, insaciabilidade, e [de] fazer[em] do vício virtude $[\ldots]^{16}$

Ao escutar o filósofo, Hipócrates convenceu-se de que Demócrito não estava doente! Ao contrário, ele era sábio; aliás, o único que poderia tornar sábios os homens do mundo. Mais ainda, o correto entendimento do riso do filósofo trará o conhecimento do riso como o melhor remédio que o médico pode prescrever. A eutimia é originada do riso ${ }^{17}$.

Entre os pré-socráticos de Heidegger não está Demócrito, raramente referido e quase sempre por relação ao atomismo. Ao contrário, Heráclito sim! Apesar de Heidegger não se referir ao vínculo entre melancolia e riso, ou a uma noção de existência própria na eutimia, e menos ainda a alguma ligação expressa entre poesia e comédia, talvez se possa chegar a uma interpretação que revele a dignidade do cômico e do risível no pensamento ontológico. Apesar de significativas, as quatro passagens comentadas não esboçam nenhuma consideração essencial sobre as relações entre a comédia e a obra de arte, entre o risível e a poesia, ou entre verdade e humor, o ser e o risível. Caso exista um ponto de inflexão que conduza até a verdade da comédia e ao risível no ser, ele poderá ser alcançado apenas com a apropriação das indicações fornecidas por Heidegger. Além disso, como não há um tratamento sistemático do tópico, não é possível examinar as sugestões de Heidegger no contexto da história

\footnotetext{
${ }^{16}$ Citado a partir da tradução de Verena Alberti (1999, p. 75-76), e do texto inglês em Robert Burton (1977, p. 47-52).

${ }^{17}$ Sobre a ética de Demócrito, ver Jonnathan Barnes (1979, p. 530-535).
} 
das teorias sobre o riso e o cômico.

Para dar um passo em direção a essa interpretação sistemática é preciso abordar a pergunta pelas razões da ausência da comédia e do risível na analítica da existência, na ontologia fundamental e no pensamento da história do $\operatorname{ser}^{18}$. Um ponto de partida promissor seria uma explicação por analogia com a ausência de tematização do sublime. Também o termo "sublime" é pouco ou raramente empregado por Heidegger, mas isso não implica a falta de visualização do fenômeno. Talvez o conceito do sublime possa ser encontrado no núcleo do pensamento de Heidegger sobre o ser. Segundo Young (2001, p. 123), se o termo "sublime" pouco aparece na obra de Heidegger, pois estaria subordinado à noção de sagrado, o esquecimento de ser pode ser entendido como o esquecimento da sublimidade de ser. Por outro lado, Heidegger teria uma forte resistência em considerar o pensamento do ser a partir de algum fenômeno abordado na filosofia ocidental da arte, dado que essa tradição pertenceria à história da metafísica ${ }^{19}$.

Por analogia, a falta de tematização do risível e do cômico não implicaria o desconhecimento da relevância do fenômeno para o problema do ser. Uma diferença importante em relação ao sublime seria que no risível e no cômico não entra em questão apenas a estética e a filosofia da

\footnotetext{
${ }^{18}$ Há uma dificuldade adicional aqui, pois qualquer hipótese explicativa deve abordar o problema do vínculo entre o riso e a corporeidade. Esse é um elemento presente desde a análise de Aristóteles, que encontrou nas teorias modernas o seu ponto culminante na explicação do assim chamado "ciclo do riso" (ALBERTI, 1999, cap. 3). A referência à corporeidade também é central na caracterização de Helmuth Plessner (1941, p. 203), que entende o riso como "reação à crise do comportamento do homem". O tópico supõe, portanto, a reconstrução da noção de corporeidade no pensamento ontológico de Heidegger.

${ }^{19}$ Desse modo, a ausência do termo "sublime" seria baseada na homogeneização da tradição filosófica, ignorando a dicotomia entre o sublime e o belo, assim como as respectivas tradições de abordagem dos dois fenômenos (YOUNG, 2001, p. 43, nota 43). Sobre a discussão em torno da falta de consideração do fenômeno do sublime na obra heideggeriana, ver Reis (2008).
} 
arte, mas também a retórica. Não seria um artifício sistemático sustentar que a retórica, reduzida a uma disciplina sobre argumentação ou conjunto de técnicas de persuasão, também estaria sob o esquecimento do ser e sob o manto da metafísica. No entanto, se o comentário das passagens citadas torna admissível a hipótese que o risível e o cômico formam o impensado na obra de Heidegger, então se abre uma dupla direção de interpretação: construção e destruição meditativa.

$\mathrm{Na}$ via meditativa há uma busca do que permaneceu esquecido nos caminhos do pensamento de Heidegger. Nesse último caso, a história do tratamento do risível permitiria um acesso àquilo que estaria não pensado na preparação da superação da metafísica. $O$ cômico poderia mostrar algo do que ficou esquecido no próprio pensamento heideggeriano. Essa via é bem mais difícil de percorrer, porque supõe a reconstrução construtiva das indicações formais sobre o risível. Os problemas metodológicos são extremamente complicados nessa perspectiva, pois até mesmo a natureza conceitual do pensamento da história do ser precisaria ser posta à luz de uma abordagem não metafísica do risível.

$\mathrm{Na}$ via construtiva, busca-se a apropriação das indicações formais sobre o risível. Nessa direção, o projeto da ontologia fundamental proporciona a base para uma ciência ontologicamente adequada do risível e da comédia (também como arte dramática). Desse ponto pode resultar uma discussão crítica da dualidade de abordagens, que tem sido reconhecida na história da teoria do risível, a saber, uma orientação essencialista (a procura da essência do risível e do riso) e outra histórica (o exame das concepções existentes sobre o riso, para deduzir a relação entre riso e pensamento, 
chegando, por fim, ao pensamento como tal) ${ }^{20}$. Portanto, a analítica da existência seria uma das mediações necessárias para o tratamento científico do riso e daquilo que faz rir. Mesmo os estudos naturalizados e empíricos sobre o riso e a gargalhada precisariam tomar por base uma ontologia da existência como possibilidade ${ }^{21}$. Em termos filosóficos, a hermenêutica fenomenológica do risível e do riso representa uma perspectiva original de tratamento do fenômeno do humor, em particular das piadas e também dos textos para rir $^{22}$. Sob a ótica da destruição da história da ontologia, a hermenêutica do risível desvenda os pseudoproblemas nas teorias filosóficas do riso, originados precisamente do esquecimento do problema do ser e da identidade existencial humana. Resulta, portanto, em uma apropriação destrutiva do que ficou esquecido na história da teoria do risível.

No pensamento da história do ser, por um lado, pode ser formulado o problema de se o enigma do cômico é pensável na história da metafísica. Como é pensado o riso na era da técnica? Que tipo de riso deixa de ser possível na instalação técnica do ente em seu todo? A maquinação exclui alguma das formas do risível? A história da metafísica esta-

\footnotetext{
${ }^{20}$ Dado o caráter muito especial do antiessencialismo e da historicidade da obra de Heidegger, seria possível encontrar na construção das indicações formais sobre o risível uma justificativa para a referida dualidade de tratamentos do fenômeno do riso (ALBERTI, 1999, p. 35-36).

${ }^{21}$ É muito informativo o estudo de Robert Provine (2000), que recusa a via de uma abordagem teórica e filosófica em detrimento de uma pesquisa empírica e naturalizada. Talvez a premissa que justifica a abordagem naturalizada possa ser problematizada a partir de uma concepção mais rica da relação entre filosofia e ciência (idem, p. 11). No entanto, considerando a hermenêutica circular, que admite uma cooperação entre interpretação ontológica e pesquisa científica, os resultados da investigação de Provine são altamente relevantes para o desenvolvimento construtivo aqui mencionado.

${ }^{22}$ Um exemplo muito iluminador é o livro de Simon Critchley (2002, p. 12, p. 16-18, p. 79-90), em que o humor é descrito como revelador da situação em que nos encontramos, ao exibir o pano de fundo de significados partilhados no mundo. O humor proporcionaria uma fenomenologia oblíqua da vida cotidiana, uma fenomenologia cômica, inclusive operando de modo análogo à angústia (idem, p. 20-21, 74-75).
} 
ria refletida também na história do pensamento do riso e do risível? Por outro lado, o pensamento não calculador seria capaz de preservar o mistério do risível, a relação entre o cômico e o acontecimento apropriativo? A linguagem preparatória para a superação da metafísica e do novo começo na história do ser preservaria a possibilidade de surgimento do cômico e do risível? Quando acontece na linguagem o fenômeno do cômico, haveria algo daquilo que pretende estar abrigado no pensamento essencial, revelando, assim, uma ligação muito íntima entre o sagrado e o risível? Um pensamento feito a partir da mesma possibilidade na qual nascem a comédia e a tragédia não estaria distante, talvez, de uma preparação para o fim da estética e da metafísica.

Entretanto, o problema de base em uma ontologia do risível não é apenas o de exibir as condições para toda filosofia ou ciência do riso. Também é preciso perguntar se a destruição da história da ontologia e o ultrapassamento da metafísica não são as condições para a identificação do originariamente risível. Nesse sentido, o aparente obstáculo terminológico proporcionado pela classe de expressões para o risível - humor, ironia, comédia, piada, dito espirituoso, brincadeira, sátira, grotesco, gozação, ridículo, farsa, humor negro, palhaçada, jogo de palavras, jogo, etc. - pode ter significação categorial para o tema. Não haveria no pensamento do ser um conceito de jogo que possibilitasse a unidade originária na diferença entre o riso cômico e o riso trágico? Em outros termos, pode rir aquele que compreende o pensamento essencial e que riso é esse? Pode haver riso no habitar poeticamente o mundo? Essas perguntas não serão abordadas aqui. Como não disponho dos elementos para respondê-las, comentarei, a título de conclusão, uma passagem excepcionalmente apropriada, extraída do curso sobre 
Heráclito anteriormente citado.

\section{O RISÍVEL NO JOGO DO PENSAMENTO}

$\mathrm{Na}$ interpretação do Fragmento 123 de Heráclito, Heidegger (1943, p. 137) afirma que:

Toda "essência" é, na verdade, desprovida de imagem. Entendemos incorretamente isso como uma falta. Esquecemos, assim, que é o desprovido de imagem, o não intuitivo, portanto, que primeiramente confere fundamento e necessidade a tudo que é passível de imagem. $\mathrm{O}$ que poderia pintar um pintor que não visse sempre mais amplamente e além do que as cores e os traços oferecem? Sem o não intuitivo, que permite ver algo, todo intuitivo é apenas um estímulo visual. O grito cada vez mais estridente pela "intuitividade" já perdeu o cômico e encaminhou-se diretamente para se tornar o sinal do trágico, isto é, de uma vontade que, querendo a si mesma, só consegue querer contra si e age contra si mesma, e nisso até aparecendo "logicamente".

Essa é uma passagem importante, porque relaciona o cômico e o trágico, permitindo uma interpretação sobre a relação de ambos com o pensamento. Em Heidegger's heraclitian comedy, Bernard Freydberg (2007) interpreta o trecho, destacando o possível vínculo entre o cômico e o pensamento. Com razão ele observa que o texto referido desperta muitas perguntas, sendo muito diferente da outra referência ao cômico presente no mesmo curso (e que foi comentada anteriormente). Qual o vínculo entre o intuitivo e o cômico? Porque o grito estridente põe o cômico a perder? $\bigcirc$ trágico e o cômico se excluem mutuamente? Como entender a caracterização do trágico em termos da vontade atuando em contra de si mesma? Isso significa que a vontade chega a aparecer como algo 'lógico'? Por que o grito por intuitividade é estridente, e não um chamado tranquilo? Por fim, Hei- 
degger sustentaria que o pensamento admite uma apropriação do cômico? ${ }^{23}$ Freydberg oferece, para essas perguntas, as seguintes conclusões:

1. Não há uma exclusão entre o cômico e o trágico, mas esses dois momentos devem ser entendidos como as maneiras com as quais os mortais se comportam diante do que lhes é entregue como um dom, a saber, a emergência e o auto-ocultamento de ser. O cômico pode se tornar trágico e o trágico pode recuperar o cômico. Cômico e trágico são as faces visíveis do modo com que os mortais vivem seus destinos, as maneiras como chegam a ser propriamente mortais; 2. A interpretação do trágico pelo padrão da vontade, uma vontade que quer contra si mesma ao querer a si mesma, implica que o cômico pode significar uma dupla direção de negação: a) um querer em acordo com si mesmo ao querer a si mesmo (e não um querer contra si mesmo), ou b) o cômico seria um não querer pura e simplesmente. A relação entre o cômico e a vontade será concebida, então, como uma vontade que não quer a si mesma, portanto, como uma saída do volitivo; 3 . A intuitividade é o signo do trágico, pois a exigência de acessibilidade e visibilidade é a exigência de que tudo esteja completamente desvelado. A vontade de um desvelamento pleno e ilimitado, a perda do mistério e do sublime, conteria em si as sementes de sua própria destruição. O clamor por intuitividade seria um grito estridente, pois a cada descobrimento intuível sempre há algo de encobrimento, fazendo com que a demanda por

\footnotetext{
${ }^{23} \mathrm{O}$ artigo inicia com uma elucidação e uma defesa da tradução heideggeriana do Fragmento 123, para então examinar detalhadamente os vínculos na tradução das palavras $\Phi u ́ \sigma / \zeta, ~ K \rho u ́ m t \varepsilon \sigma \theta \alpha I ~ e$

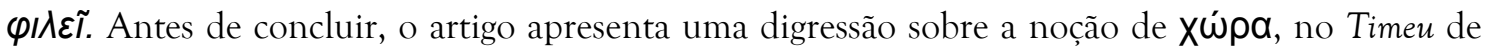
Platão, com o objetivo de oferecer uma interpretação para o não intuível da essência. A conclusão do artigo apresenta sugestões de resposta para as perguntas citadas.
} 
progresso no desvelamento nunca termine; 4. A perda do cômico refere-se ao fechamento da dimensão do não volitivo, de uma vontade que não quer a si mesma. A relação entre o pensamento e a comédia é radical, ou seja, relativa não propriamente à arte dramática ou a um texto feito para rir, mas sim àquilo que está na raiz primitiva da comédia: o $\kappa \tilde{\omega} \mu$ os. Essa seria a imagem de uma humanidade que se entrega ao jogo de desvelamento e retração sem pretender dominar o jogo da $\Phi v \sigma l \varsigma$. A comédia heraclitiana consiste no reconhecimento que o pensamento mais poderoso não é o mais seguro e audaz, mas sim o mais modesto e sem utilidade, aquele pensamento que se retrai para permitir que o

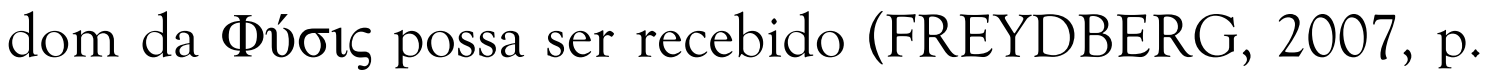
266-267).

As conclusões de Freydberg podem ser avaliadas criticamente, especialmente no tocante ao apoio documental oferecido, mas não me voltarei para esse ponto. As considerações do presente ensaio evidenciaram o traço eminentemente interpretativo requerido para enfocar o tópico do risível à luz da obra de Heidegger. Parece-me correto dizer que a interpretação da comédia heraclitiana exibiu duas condições básicas para o desenvolvimento construtivo do fenômeno do cômico na obra de Heidegger: a relação com o trágico e a relação entre pensamento e vontade. Sobre essas condições, registro três comentários provisórios.

Primeiro, o padrão interpretativo para o trágico - a vontade querendo contra si mesma ao querer a si mesma permite uma ligação heuristicamente relevante com o cômico. Pela via de uma reconstrução do tratamento da tragédia ao longo da obra de Heidegger é possível chegar a uma interpretação concreta da possível abordagem da comédia no pensamento do ser. A análise comparativa com a interpre- 
tação da tragédia, como poetar pensante dos gregos (HEIDEGGER, 1953, p. 110), contém a dificuldade promissora proporcionada pela mudança na interpretação de Antígona, de 1935 para $1942^{24}$. Não significaria tal mudança também uma virada em direção àquilo que poderia haver de jogo, festivo e risível no poético da linguagem? Haveria um paralelo entre a evolução na concepção do trágico e o reconhecimento do cômico? E se é correto que a concepção da obra de arte em A origem da obra de arte é apenas um momento inicial no pensamento sobre a arte, a educação que Heidegger recebeu de Hölderlin (YOUNG, 2001, p. 71-72) não seria também responsável pela admissão da dignidade da comédia e do risível?

Segundo, a elucidação do cômico por recurso à dinâmica da vontade é iluminadora, mas apresenta dificuldades reconstrutivas significativas. Creio que a análise da copertinência entre o trágico e o cômico ganharia muito em desenvolvimento pela introdução da distinção entre o domínio da vontade e o campo da serenidade avolitiva. $\mathrm{O}$ campo da vontade abarca a forma direta da volição enquanto incorporação extática, além das variações oblíquas do querer: recalcamento, encobrimento e submissão da vontade (DAVIS, 2007, p. 1-23). Situar o cômico no plano do avolitivo pura e simplesmente, como uma vontade que simplesmente não quer a si mesma, permite a passagem para a relação com o pensamento por meio de uma conexão com o conceito de serenidade (Gelassenheit). $\mathrm{O}$ conceito de negação torna-se central para esse problema, pois assim como o plano do avolitivo não é definido pela negação sim-

\footnotetext{
${ }^{24}$ Da já extensa literatura sobre a interpretação heideggeriana da tragédia e de Antígona reportome apenas aos artigos de Véronoqui Fóti (1999) e de Clare Geiman (2001).
} 
ples da vontade, mas é a saída de todo campo do volitivo, também a relação entre a comédia e a tragédia não seria a de uma negação inqualificada ${ }^{25}$.

Por fim, o exame da relação entre o cômico e o pensamento pela mediação do conceito de vontade tem como suposto a relativização da noção de vontade como uma faculdade subjetiva (DAVIS, 2007, p. 5-9). Desse suposto resultam duas importantes consequências: a restrição da análise das volições e desejos como estados mentais, e, sobretudo, a dependência da distinção entre pensamento e vontade em relação a um fenômeno mais originário da vontade. Tal noção de vontade se faz compreensível porque a intuitividade põe o cômico a perder, pois a exigência de representação, que sempre implica uma demanda por visualização ou acesso, é o sinal da pertinência ao campo do volitivo. $O$ pensamento como um modo da incorporação extática seria trágico, ao passo que um pensar na serenidade seria cômico, no sentido do desligamento do domínio da vontade.

Além disso, o desligamento da vontade corresponderia à resposta adequada para a preservação do jogo de emergência e velamento de ser. $\mathrm{O}$ fenômeno do jogo, entendido na acepção originária da livre formação da transcendência para ser, está presente também no modo de acontecimento do pensamento avolitivo. É oportuno recordar que, ao tematizar o conceito de jogo, Heidegger formulou um sentido originário do jogar, em relação ao qual todos os jogos seri-

\footnotetext{
${ }^{25}$ Não abordarei o problema da relação entre o trágico e o lógico (ver FREYDBERG, 2007, p. 265, n. 6). Apenas destaco que, na interpretação das Cartas para a educação estética da humanidade, Heidegger (2005, p. 87) afirmou que somente uma "lógica cômica" se ocupa com proposições isoladas. Não é artificial vincular a lógica com o conceito de vontade, dado que o pensamento predicativo-proposicional foi vinculado por Heidegger ao querer enquanto incorporação extática (DAVIS, 2007, p. 6).
} 
am conformações fácticas (REIS, 1999). Caso se aceite a interpretação de Freydberg, então o cômico e o trágico seriam as possibilidades históricas de respostas formativas ao jogo de ser. Um pensamento cômico, fora do âmbito de uma vontade que quer a si mesma, não buscaria o desvelamento sem retração. Ao contrário, ele estaria subordinado ao acontecer de um jogo de desvelamento e retração que sempre preserva o oculto de todo desocultamento. A autoridade normativa de mundo - tributária do factum de em todo desvelamento estar preservada uma fecundidade oculta - não é exatamente aquilo que se torna tema no cômico e no risível? Assim sendo, a comédia não ganharia, então, a dimensão do traçado contencioso de terra e mundo? ${ }^{26}$

Se o cômico é uma resposta ao dom sublime do aparecer e ocultar-se de ser, então um pensamento essencial e não calculador seria aquele que pensasse o habitar poético no mundo e como tal deveria preservar em si algo do cômico. No entanto, a comicidade do pensamento essencial não poderia mais ser vista a partir da risibilidade com a qual o pensar filosófico aparece para o pensamento calculador. Como já foi sugerido, talvez a risibilidade do "outro pensar" não possa ser caracterizada nem como trágica, nem como cômica. A pobreza de tal pensamento seria, portanto, o signo da adequação ao jogo de ser. $\mathrm{O}$ pensar avolitivo e o riso respondem ao sublime sem pretender transcendê-lo, preservando a finitude de ser e da existência humana. Caso essa interpretação seja sustentável, então se entende porque o poder do cômico não é transcendente (CRITCHLEY,

\footnotetext{
${ }^{26}$ Sobre a interpretação normativa da verdade como ocultamento e desocultamento, ver Fred Rush (2001, p. 210). Sobre a festa e jogo na arte, ver Gadamer (1975) e também Figal (1996).
} 
2002, p. 16-17).

Wittgenstein teria observado que "se poderia escrever uma obra filosófica boa e séria composta inteiramente de piadas" (PAULOS, 1994, p. 15). Pensamentos e piadas podem não ser entendidos. Sem a intimidade do cômico, não há o riso. Pensamentos filosóficos podem fazer rir da piada, e o humor revela a situação hermenêutica. Mas a filosofia também pode ser cômica em outro sentido: o riso dá acesso ao que deve ser pensado. Se o riso acontece, é porque se pensa essencialmente. A atenção promovida no riso não seria aquela necessária para pensar a linguagem dos poetas? Talvez. Sendo aceitável a distinção entre o risível originário e o risível particular, então no cômico fáctico sempre haveria algo do cômico originário. Sob tais condições faz sentido falar de um enigma da comédia: em todo aparecer do cômico estaria preservada a fecundidade do cômico originário, algo do jogo primordial que não se situa no domínio da vontade, mas pertence ao âmbito da serenidade. $\mathrm{O}$ riso seria, por fim, a resposta diante do que fica velado em toda manifestação, e o campo da serenidade possibilitaria situar uma conexão muito especial entre o sublime, o sagrado e o risível.

Com o modelo econômico de explicação do aparelho mental, Freud ofereceu uma elucidação do chiste, do cômico e do humor como sendo o restabelecimento mental de um prazer perdido ao longo do desenvolvimento da atividade psíquica. A euforia buscada é uma tonalidade afetiva comum na infância. Segundo Freud (1905, p. 265), na infância se ignora o cômico, se é incapaz do chiste e não é preciso humor para sentir felicidade na vida. Essas observações são de cunho psicológico e não se situam no plano ontológico. O modelo econômico de explicação tampouco 
satisfaz a condição de descentramento subjetivo que Heidegger progressivamente torna mais restritiva ao longo de sua obra. No entanto, as considerações de Freud indicam uma historicidade na qual o elemento risível surge ao longo de uma história de perdas.

Vinculado aos conceitos de ser e pensamento, o conceito de jogo discrimina um padrão do acontecer histórico no qual também o cômico e o trágico podem ser vistos em relação histórica. Como história de perdas, a história de ser é uma história de abandono e de esquecimento. Há também uma perda do risível, do originariamente cômico? É possível uma recuperação? Até onde compreendo, com a superação da metafísica não acontece um retorno a uma origem adequada, mas talvez uma serenidade para deixar a técnica, uma serenidade para o jogo de $\operatorname{ser}^{27}$. Heidegger responde a objeção de que conceitualizar ser pela noção de jogo (e do risível, segundo a minha hipótese) seria infantilizar o que é sério.

Inicialmente, ele afirma que não se pode pensar o jogo e a brincadeira como algo especificamente infantil. Além disso, se o jogar e o brincar são privilégios da criança, então isso implica que o jogo pertence ao homem. E mais: "Talvez a criança só seja criança, porque ela é algo em um sentido metafísico que nós adultos não concebemos mais de maneira alguma" (HEIDEGGER, 1996, p. 310-311). Assim sendo, compreender algo do jogo originário seria uma recordação do modo como acontece a ligação infantil à formação livre do jogar, que pode ser também a formação

\footnotetext{
${ }^{27}$ Deixar a técnica, não como retorno a algum estágio não tecnológico, mas como "a atitude do sim e do não simultâneos em relação ao mundo técnico" (HEIDEGGER, 1959, p. 23).
} 
do cômico e do risível ${ }^{28}$. As considerações finais de $\mathrm{O}$ princípio de razão, segundo as quais o pensamento da história de ser precisaria pensar fundamento e ser a partir do jogo, também motivam uma ampliação da conexão conceitual entre ser e o risível. A criança crescida brinca e joga o jogo de mundo sem um 'porquê' (HEIDEGGER, 1957, p. 169). Assim como o jogo é sem porque, não se deveria dizer o mesmo do riso e do risível? E se há um mistério do jogo que é impensável para o pensamento que representa o jogar como algo (idem, p. 167 e 169), talvez também seja legítimo falar de um mistério do riso, ao qual também apenas um tipo não habitual de pensamento é adequado. Admitindo tal suposição, então a afirmação que a morte é a medida do jogo mais elevado no qual o homem está posto (idem, p. 167) já é uma recomendação para pensar o mistério do risível no plano a partir do qual pode se originar o riso cômico e o riso trágico.

$\mathrm{Na}$ primeira seção do presente ensaio apresentei a tese de Dieter Tomä acerca das razões de a obra heideggeriana ter gerado uma história de sátiras. Se o cômico pode ser visto como o impensado na obra de Heidegger, um aspecto relevante para ver o pensamento do ser sob a luz reveladora do humor e do risível é a etnicidade do cômico. O humor está enraizado de maneira diferente nos diferentes povos. Assim como os povos históricos guardam em si o acontecimento apropriativo de ser, também se conhecem povos humorados e menos humorados ${ }^{29}$. E se o esquecimento do

\footnotetext{
${ }^{28}$ Uma análise dos jogos de palavras freqüentes nos textos de Heidegger excede os limites da presente contribuição, apesar da evidente conexão com o problema da anamorfose como estratégia metodológica. Ver a sugestão de Brodbeck (2003) para interpretar a dinâmica dos jogos lingüísticos nos termos das Ars magna de Ramon Lull.

${ }^{29}$ Basta lembrar a seguinte consideração de Eliot (apud CRITCHLEY, 2002, p. 70): "Uma comé-
} 
sublime também é o esquecimento do jogo e do cômico, não seria a risibilidade do pensamento um traço da serenidade que também se refletiria no solo relativo do humor? Nesse sentido, ao contribuir decisivamente para a história da sátira à filosofia, a obra de Heidegger também pode ser vista como um testemunho vigoroso de uma correspondência ao enigma da comédia.

Abstract: The main purpose of this paper is the formulation of a hypothesis about the internal link between the laughing and the thinking of Being, offering some guidelines for a systematic treatment of the issue of the comical in Heidegger's work. I conclude the paper with a remark on the relation between the comical, the tragic and the thinking, having Heidegger's interpretation of Heraclitus as a starting point.

Keywords: Heidegger, comical, laughing, thinking of being.

\section{REFERÊNCIAS}

ALBERTI, Verena. O riso e o risível na história do pensamento. Rio de Janeiro: Jorge Zahar Editor, 1999.

ARISTÓTEleS. Poética. São Paulo: Abril Cultural, 1973. p. 443-525. (Coleção Os Pensadores)

BARNES, Jonathan. The presocratic philosophers. [1979]. London and New York, Routledge: 1996.

BRODBECK, Karl-Heinz. Wort-Speile in der offenen Weite. Heideggers Denken im Licht der lullischen Kunst. In: ULLRICH, Wolfgang (HG.). Verwindungen. Frankfurt am Main: Fischer Taschenbuch Verlag, 2003. p. 123-137. BURTON, Robert. The anatomy of melancholy. [1621]. chegar ao fim, e a conclusão é aceita como um arranjo da Providência e não do autor”. 
New York: Vintage Books, 1977.

CICERO. De oratore. Disponível em: http://www. uniregensburg.de/Fakultaeten/phil_Fak_IV/Klass

_Phil/Paginaciceroniana.htm.

COHEN, Ted. Jokes. Philosophical thoughts on joking matters. Chicago and London: University of Chicago Press, 1999.

COOPER, Lane; ALADRO, Eva. Tradução e comentário ao Tractatus Coislinianus. Cuadernos de Información y Comunicación 7, p. 31-37, 2002.

CRITCHLEY, Simon. On humor. London and New York: Routledge, 2002.

DAVIS, Bret. Heidegger and the will. On the way to Gelassenheit. New York: SUNY, 2007.

ECKHART, Mestre. A excelência de Marta sobre Maria. In: O Livro da Divina Consolação e outros textos seletos. Petrópolis, Vozes, 1994. p. 170-179.

FIGAL, Günter. Kunst als Weltdarstellung. In: Der Sinn des Verstehens. Stuttgart: Reclam, 1996. p. 45-63.

FÓTI, Veronique M. Heidegger, Hölderlin, and sophoclean tragedy. In: RISSER, James. Heidegger toward the turn. New York: SUNY, 1999. p. 163-186.

FREUD, Sigmund. Os chistes e sua relação com o inconsciente. [1905]. In: Edição Standard Brasileira das Obras Psicológicas Completas de Sigmund Freud. v. VIII. Rio de Janeiro, Imago Editora: 1977. 
FREYDBERG, Bernard. Heidegger's Heraclitean comedy. Research in Phenomenology, n. 37, p. 254-268, 2007.

GADAMER, H-G. Die Aktualität des Schönen. Kunst als Spiel, Symbol und Fest. [1974]. In: Gesammelte Werke 8. Tübingen: J. C. B. Mohr, 1993. p. 94-142.

GEIMAN, Claire Pearson. Heidegger's Antigones. In: POLT, R.; FRIED, G. Heidegger's introduction to Metaphysics. New Haven and London: Yale University Press, 2001. p. 161-182.

HEIDEGGER, Martin. Sein und Zeit (17. Auflage). [1927]. Tübingen: Max Niemeyer Verlag, 1986.

. Was ist Metaphysik? (9. Auflage) [1929]. Frankfurt am Main: Vittorio Klostermann, 1965.

- Der Ursprung der Kunstwerk [1949]. In: Holzwege. Gesamtausgabe 5. Frankfurt am Main: Vittorio Klostermann: 1977.

. Einführung in die Metaphysik (6. Auflage) [1953]. Tübingen: Max Niemeyer Verlag, 1998.

. Der Satz vom Grund [1957]. In: Gesamtausgabe 10. Frankfurt am Main: Vittorio Klostermann, 1997.

- Gelassenheit (13. Auflage) [1959]. Stuttgart: Klett-Cotta: 2004.

. Die Frage nach dem Ding (3. Auflage) [1962]. Tübingen: Max Niemeyer, 1987.

. Heraklit. Gesamtausgabe 55. Frankfurt am Main: Vittorio Klostermann, 1979. 
Vom Ursprung des Kunstwerkes: Erste Ausarbeitung. Heidegger Studien 5, p. 5-22, 1989a.

- Beiträge zur Philosophie. Vom Ereignis. In: Gesamtausgabe 65. Frankfurt am Main: Vittorio Klostermann, 1989b.

- Platon: Sophistes. In: Gesamtausgabe 19 (Wintersemester 1924/25). Frankfurt am Main: Vittorio Klostermann, 1992.

. Einleitung in die Philosophie. In: Gesamtausgabe 27 (Wintersemester 1928/29). Frankfurt am Main: Vittorio Klostermann, 1996.

. Vom Wesen der Wahrheit. In: Gesamtausgabe 34 (Wintersemester 1931/32). Frankfurt am Main: Vittorio Klostermann, 1998.

- Vom Wesen der Sprache. Zu Herders Abhandlung "Über den Ursprung der Sprache. In: Gesamtausgabe 85 (Sommersemester 1939). Frankfurt am Main: Vittorio Klostermann, 1999.

. Übungen für Anfünger. Schillers Briefe über die ästhetische Erziehung des Menschen (Wintersemester 1936/37). Marbach am Neckar: Deutsche Schillergesellschaft, 2005.

IJSSELING, Samuel. Mimesis and Translation. In: SALLIS, John. Reading Heidegger. Bloomington and Indianapolis: Indiana University Press, 1993. p. 348-351.

MONTAIGNE, Michel. Ensaios. São Paulo: Abril Cultural, 1984. (Coleção Os Pensadores) 
PAULOS, John Allen. Pienso, luego rio. Madrid: Cátedra, 1994.

PLATÃO. Filebo. In: Diálogos. Belém: Universidade Federal do Pará, 1973.

PLESSNER, Helmuth. Lachen und Weinen (3. Auflage) [1941]. Bern und München: Francke Verlag, 1961.

PROVINE, Robert. Laughter. A scientific investigation. New York: Penguin Books, 2000.

QUINTILIANO. Institutio Oratoria. http://penelope. uchicago.edu/Thayer/E/Roman/Texts/Quintilian /Institutio_Oratoria/home.html.

REIS, Róbson Ramos dos. Heidegger, a transcendência como jogo. Praxis Filosófica, v. 10, n. 11, p. 341-353, 1999.

. O sublime e o natural hermeneuticamente revisitados. Natureza Humana, v. 10, n. 2, 2008. No prelo.

RITTER, Joachim. Sobre la risa. (1940). In: Subjetividad. Barcelona: Editorial Alfa, 1986. p. 53-79.

RUSH, Fred. The availability of Heidegger's later thought. Inquiry, n. 44, p. 201-222, 2001.

SALLIS, John. Heidegger's poetics: the question of mimesis In: MACCANN, Christopher. Martin Heidegger. Critical Assessments, v. IV. London and New York: Routledge, 1992. p. 267-278.

STEIN, Ernildo. Anamorfose e profundidade: as armadilhas da interpretação. O que nos faz pensar? Rio de Janeiro, v. 2, n. 10, p. 25-36, 1996. 
TOMÄ, Dieter. Am Ab-Ort des Seins. Lächerliches und erhabenes in Heideggers Philosophie. In: ULLRICH, Wolfgang. Verwindungen. Frankfurt am Main: Fischer Taschenbuch Verlag, 2003a. p. 89-109.

. Heidegger in die Satirie. Das Herrchen des Seins. In: Heidegger Handbuch. Stuttgartt: J. B. Metzler, 2003b. p. 510-513.

TRAWNY, Peter. Über die ontologische Differenz in der Kunst. Ein Rekonstruktionsversuch der "Überwindung der Aesthetik" bei Heidegger. Heidegger Studien 10, p. 207-221, 1994.

YOUNG, Julian. Heidegger's Philosophy of Art [2001]. Cambridge: Cambridge University Press Nerlag, 2002. p. 135-151. 